\title{
Proteolytic activation of the epithelial sodium channel (ENaC) by factor VII activating protease (FSAP) and its relevance for sodium retention in nephrotic mice
}

\author{
Ferruh Artunc ${ }^{1,2,3}$ (D) Bernhard N. Bohnert ${ }^{1,2,3} \cdot$ Jonas C. Schneider ${ }^{1} \cdot$ Tobias Staudner $^{4} \cdot$ Florian Sure $^{4}$. \\ Alexandr V. Ilyaskin ${ }^{4} \cdot$ Matthias Wörn ${ }^{1} \cdot$ Daniel Essigke $^{1,2,3} \cdot$ Andrea Janessa $^{1} \cdot$ Nis V. Nielsen ${ }^{5}$. \\ Andreas L. Birkenfeld ${ }^{1,2,3} \cdot$ Michael Etscheid $^{6} \cdot$ Silke Haerteis $^{4,7} \cdot$ Christoph Korbmacher $^{4} \cdot$ Sandip M. Kanse $^{5}$
}

Received: 26 August 2021 / Revised: 5 October 2021 / Accepted: 18 October 2021 / Published online: 6 December 2021

(c) The Author(s) 2021

\begin{abstract}
Proteolytic activation of the epithelial sodium channel $(\mathrm{ENaC})$ by aberrantly filtered serine proteases is thought to contribute to renal sodium retention in nephrotic syndrome. However, the identity of the responsible proteases remains elusive. This study evaluated factor VII activating protease (FSAP) as a candidate in this context. We analyzed FSAP in the urine of patients with nephrotic syndrome and nephrotic mice and investigated its ability to activate human ENaC expressed in Xenopus laevis oocytes. Moreover, we studied sodium retention in FSAP-deficient mice $\left(\mathrm{Habp2}^{-/-}\right)$with experimental nephrotic syndrome induced by doxorubicin. In urine samples from nephrotic humans, high concentrations of FSAP were detected both as zymogen and in its active state. Recombinant serine protease domain of FSAP stimulated ENaC-mediated whole-cell currents in a time- and concentration-dependent manner. Mutating the putative prostasin cleavage site in $\gamma$-ENaC ( $\gamma$ RKRK178AAAA) prevented channel stimulation by the serine protease domain of FSAP. In a mouse model for nephrotic syndrome, active FSAP was present in nephrotic urine of $\mathrm{Habp2}^{+/+}$but not of $\mathrm{Habp}^{-/-}$mice. However, Habp2 $2^{-1-}$ mice were not protected from sodium retention compared to nephrotic $\mathrm{Habp}^{+/+}$mice. Western blot analysis revealed that in nephrotic Habp2 $2^{-/-}$ mice, proteolytic cleavage of $\alpha$ - and $\gamma$-ENaC was similar to that in nephrotic $H a b p 2^{+/+}$animals. In conclusion, active FSAP is excreted in the urine of nephrotic patients and mice and activates $\mathrm{ENaC}$ in vitro involving the putative prostasin cleavage site of $\gamma$-ENaC. However, endogenous FSAP is not essential for sodium retention in nephrotic mice.
\end{abstract}

Keywords Factor VII activating protease $\cdot$ FSAP-HABP2 $\cdot$ Serine protease $\cdot$ Epithelial sodium channel $($ ENaC) $\cdot$ Nephrotic syndrome

Ferruh Artunc and Bernhard N. Bohnert shared first-authorship.

A Commentary to this article is available online at https://doi.org/ 10.1007/s00424-021-02644-w

Ferruh Artunc

ferruh.artunc@med.uni-tuebingen.de

1 Department of Internal Medicine, Division of Endocrinology, Diabetology and Nephrology, University Hospital Tübingen, Tubingen, Germany

2 Institute of Diabetes Research and Metabolic Diseases (IDM) of the Helmholtz Center Munich at the University Tübingen, Tubingen, Germany

3 German Center for Diabetes Research (DZD) at the University Tübingen, Tubingen, Germany

\section{Introduction}

Proteinuria, sodium retention and edema are hallmarks of patients with acute nephrotic syndrome. Considerable evidence has emerged that aberrantly filtered serine

4 Institute of Cellular and Molecular Physiology, Friedrich-Alexander University Erlangen-Nürnberg, Erlangen, Germany

5 Institute of Basic Medical Sciences, University of Oslo, Oslo, Norway

6 Paul Ehrlich Institute, Langen, Germany

7 Institute of Anatomy, University of Regensburg, Regensburg, Germany 
proteases resulting in proteasuria mediate sodium retention in nephrotic syndrome by proteolytically activating the epithelial sodium channel $(\mathrm{ENaC})$ expressed in the distal tubule $[2,20,25,31,35]$. This concept is supported by our recent finding that the cleavage products of $\alpha$ - and $\gamma$-ENaC were upregulated in mice with experimental nephrotic syndrome [7]. Moreover, treatment with the serine protease inhibitor aprotinin prevented proteolytic $\mathrm{ENaC}$ activation and sodium retention as did the ENaC blocker amiloride [4, 7, 8, 40]. Currently, the exact identity of the essential serine proteases in experimental nephrotic syndrome remains unknown. We have demonstrated that the lack of urokinase plasminogen activator (Plau), plasmin (Plg), or plasma kallikrein (Klkbl) - all of which are aprotinin-sensitive - did not protect from sodium retention in experimental nephrotic syndrome of mice with genetic deletion of these proteins $[4,19,40]$.

In search of other relevant serine proteases, we identified factor VII activating protease (FSAP) as a highly abundant serine protease in nephrotic urine samples by a proteomic approach [39]. In urine samples from nephrotic humans and mice, FSAP was found to be the second and third most abundant active serine protease, respectively [39]. FSAP, encoded by the $H A B P 2$ gene, is a trypsin-like serine protease that is released by the liver and sensitive to aprotinin. It has a molecular weight of $64 \mathrm{kDa}$ and therefore is not expected to undergo glomerular filtration in the healthy kidney. Histones that are released upon tissue damage, inflammation, or NETosis, and represent a response to injury signal, activate the zymogen form of FSAP in the circulation [41]. Activation is due to auto-cleavage of the single chain FSAP at position 313 which causes the formation of the active two chain form. Both chains are linked by an inter-molecular disulfide bond. Once FSAP is active in the circulation, it can cleave proteins from the hemostasis and complement system as well as cellular regulators such as growth factors and receptors of the protease-activated receptor family (PARs) [11]. Analysis of substrate preference of FSAP indicates a predilection for clusters of positively charged amino acids [24]. A naturally occurring single-nucleotide polymorphism in the FSAPencoding gene (Marburg I, MI) leads to a replacement of one amino acid (G534E) in the protease domain and completely diminishes the proteolytic activity of FSAP [15]. In the plasma, the activity of FSAP is tightly controlled by a number of protease inhibitors, forming a complex with FSAP. These inhibitors include plasminogen activator inhibitor-1 (PAI-1), C1 esterase inhibitor, $\alpha 2$-antiplasmin, and last but not least antithrombin [44].

Habp $2^{-/-}$mice show no marked phenotype in unchallenged conditions but show enhanced liver fibrosis, neointimal formation, infarction after ischemic stroke, and were protected against thrombosis [11]. In these models, the lack of endogenous FSAP exacerbates the injury response and this is associated with enhanced inflammation.
So far, urinary excretion of FSAP in nephrotic syndrome has not yet been investigated. Also, it is unknown whether FSAP is able to cleave the $\gamma$-subunit of $\mathrm{ENaC}$ for proteolytic channel activation or is involved in the pathogenesis of the nephrotic syndrome. In the present investigation, we aimed to investigate the contribution of FSAP to ENaC-mediated sodium retention in nephrotic syndrome. We analyzed urine samples from nephrotic patients and investigated the ability of FSAP to activate human $\mathrm{ENaC}$ heterologously expressed in Xenopus laevis oocytes. Finally, we studied sodium retention in FSAP-deficient mice $\left(\mathrm{Habp}^{-/-}\right)$with experimental nephrotic syndrome.

\section{Materials and methods}

\section{Patient samples}

Spot urine samples were derived from patients presenting to the University Hospital Tuebingen with acute nephrotic syndrome of various etiology. These samples had been included in one previous study [39]. Patients were included after they provided written informed consent. The study was approved by the local ethics committee of the University of Tuebingen (259/2012MPG23).

\section{Mouse studies}

Experiments were performed on 3-month-old wildtype and FSAP deficient $\left(\mathrm{Habp2}^{-/-}\right)$mice generated as previously described $[9,38]$. C57/BL6-Habp2 $2^{-/-}$mice were backcrossed onto a $129 \mathrm{~S} 1 / \mathrm{SvImJ}$ background to confer susceptibility to experimental nephrotic syndrome $[1,3,5]$. Genotyping was done using PCR with the primers 5 '-GTG TTC CGT GTC CTG CTG CTA ATC GCC CTG-3' (wildtype), 5'-GAC GAA TTC ATG GAG GCT TTG CCA CAG AGT TC-3' (common), and 5'-GCA GCG CAT CGC CTT CTA TCG CCT TCT TGA C-3' (ko). Mice were kept on a 12:12-h light-dark cycle and fed a standard diet (ssniff, sodium content $0.24 \%$ corresponding to $104 \mu \mathrm{mol} \mathrm{g}{ }^{-1}$, Soest, Germany) with tap water ad libitum. Experimental nephrotic syndrome was induced after a single intravenous injection of doxorubicin (14.5 $\mu \mathrm{g} \mathrm{g}^{-1}$ body weight, Cell Pharm, Bad Vilbel, Germany) as developed by our group [1, 3, 6]. Mice were kept in their normal cages to reduce distress after doxorubicin injection and proteinuria. Daily food and fluid intake were monitored by weighing the food pellets and the water bottle. Samples of spontaneously voided urine were collected in the morning between 8 and 10 am 2 days before (baseline) and up to 10 days following doxorubicin injection. Blood samples were drawn before induction and at sacrifice on day 10. In a subset of mice, sodium balance was studied in metabolic cages on a control diet (C1000, Altromin, 
Lage, Germany, sodium content $106 \mu \mathrm{mol} \mathrm{g}^{-1}$ ) before and on the 7th day after induction of nephrotic syndrome. In another subset of mice, $\mathrm{ENaC}$ activity was determined after intraperitoneal injection of vehicle and $10 \mu \mathrm{g} \mathrm{g}^{-1}$ amiloride in $5 \mu \mathrm{g}^{-1}$ injectable water and collection of urine for $6 \mathrm{~h}$ before and on the 7th day after induction of nephrotic syndrome. All animal experiments were conducted according to the National Institutes of Health Guide for the Care and Use of Laboratory Animals and the German law for the welfare of animals, and they were approved by local authorities (Regierungspraesidium Tuebingen, approval number M 7/18 G).

\section{Laboratory measurements}

Urinary creatinine and plasma urea concentrations were measured with a colorimetric assay (Labor + Technik, Berlin, Germany), urinary protein concentration using the Bradford method (Bio-Rad Laboratories, Munich, Germany), and urinary sodium concentration with flame photometry (Eppendorf EFUX 5057, Hamburg, Germany). Both urinary protein and sodium concentration were normalized to the urinary creatinine concentration. Feces was dried, weighed, and dissolved in $1 \mathrm{M} \mathrm{HNO}_{3}$ before measuring sodium concentration using flame photometry. Plasma albumin concentrations were measured using a fluorometric kit against mouse albumin as standard (Active motif, Carlsbad, USA). Blood gas analysis was done using an IL GEM ${ }^{\circledR}$ Premier 3000 blood gas analyzer (Instrumentation Laboratory, Munich, Germany).

\section{Determination of FSAP antigen}

Rabbit polyclonal FSAP antibody $\mathrm{Ab}\left(2 \mu \mathrm{g} \mathrm{mL} \mathrm{m}^{-1}\right)$ was immobilized in microtitre plates and blocked with $3 \%$ bovine serum albumin (BSA). Diluted urine was added to the wells, and FSAP was detected by adding a monoclonal FSAP Ab $\left(2 \mu \mathrm{g} \mathrm{mL}^{-1}\right)$ followed by peroxidase couple secondary antibody. Absorbance was followed in a microplate reader EL 808 (BioTek Instruments, Winooski, OR, USA) at $450 \mathrm{~nm}$. To quantify FSAP antigen in human urine samples, we use pooled standard human plasma as well as pooled normal healthy urine spiked with plasma-purified FSAP to generate standard curves and express activity as $\mu \mathrm{g} \mathrm{mL}^{-1}$ [22]. Both standard curves gave similar results.

\section{Determination of FSAP activity}

Microtiter plates were coated as described above for antigen assay. Diluted urine was added to the wells, and pro-uPA activation was measured by adding pro-uPA (1 $\mu \mathrm{g} \mathrm{mL}^{-1}$; Saruplase, Grünenthal, Stolberg, Germany), and $0.2 \mathrm{mM}$ of the chromogenic substrate S-2444
(L-pyroglutamyl-glycyl-L-arginine-p-nitroanilinedihydrochloride) (Haemochrom Diagnostica, Essen, Germany). Absorbance was followed in a microplate reader EL 808 at $405 \mathrm{~nm}$, and results are presented as $\mathrm{mOD} \mathrm{min}^{-1}$.

\section{Western blot for FSAP expression in urinary samples}

Human urine samples were separated by 10 or $12 \%$ SDSPAGE under reducing or non-reducing conditions as indicated. Proteins were transferred onto PVDF membrane (Millipore, Billerica, MA, USA) and probed with primary antibodies which detect either FSAP zymogen at $64 \mathrm{kDa}$ or the light chain at $27 \mathrm{kDa}$ (Mab677) or the heavy chain at $50 \mathrm{kDa}$ (Mab1189). Bound antibodies were detected using horseradish peroxidase conjugated secondary antibodies (Swine anti rabbit polyclonal; P0217, Dako, Glostrup, Denmark) and the enhanced chemiluminescence detection system (Amersham-Pharmacia, GE Healthcare, Freiburg, Germany). Murine urine samples from mice were separated by $8 \%$ SDS-PAGE under non-reducing conditions. Proteins were blotted onto a nitrocellulose membrane (Amersham, UK) and probed with a primary antibody detecting FSAP zymogen at $64 \mathrm{kDa}$ (Mab570). Bound antibodies were detected with a fluorescent secondary antibody labeled with IRDye 800CW and a fluorescence scanner (Licor Odyssey, Lincoln, USA).

\section{Determination of the proteolytic activity of FSAP}

Proteolytic activity was quantified using $20 \mu \mathrm{M}$ of fluorogenic substrate Boc-Gln-Ala-Arg-AMC (Boc-QAR-AMC) (Boc: t-Butyloxycarbonyl; AMC: 7-Amino-4-methylcoumarin; R\&D systems, Abingdon, UK) in a sample volume of $100 \mu \mathrm{L}$. This substrate detects the activity of a wide range of trypsin-like proteases. The experimental protocol was similar to that described in previous reports [14, 34]. The fluorescence signal resulting from substrate hydrolysis at the cell surface was continuously recorded over a time period up to 90 min using a TECAN plate reader (360 $\mathrm{nm}$ excitation/465 nm emission wavelength).

\section{Two-electrode voltage-clamp measurements using human ENaC expressing Xenopus laevis oocytes}

Oocytes were collected from Xenopus laevis with approval of the animal welfare officer for the University of ErlangenNürnberg as described [13, 17, 23, 33, 37]. Defolliculated stage $\mathrm{V}-\mathrm{VI}$ oocytes were injected with cRNA encoding human $\alpha-, \beta$-, and $\gamma$-ENaC (0.2 ng of cRNA/subunit of human wild-type $\alpha$-, $\beta$ - and $\gamma$ - or mutant $\gamma$ RKRK178AAAA $\mathrm{ENaC}$ ). ENaC-mediated whole-cell currents were measured using the two-electrode voltage-clamp (TEVC) technique as previously described [13, 17, 18, 23]. Amiloride-sensitive 
current $\left(\Delta I_{\mathrm{ami}}\right)$ values were determined at a holding potential of $-60 \mathrm{mV}$ by washing out amiloride $(2 \mu \mathrm{M})$ with amiloridefree ND96-solution (96 mM NaCl, $2 \mathrm{mM} \mathrm{KCl}, 1.8 \mathrm{mM}$ $\mathrm{CaCl}_{2}, 1 \mathrm{mM} \mathrm{MgCl} 2,5 \mathrm{mM}$ HEPES; $\mathrm{pH} 7.4$ adjusted with Tris) and subtracting the whole-cell currents measured in the presence of amiloride from the corresponding wholecell currents recorded in the absence of amiloride. To assess the stimulatory effect of FSAP on ENaC, we used recombinant FSAP serine protease domain (FSAP-SPD, $30 \mathrm{kDa}$ ), synthesized as described before [29], and determined $\Delta I_{\mathrm{ami}}$ twice in a single oocyte (i.e. before and after exposure to the protease). After the first measurement of $\Delta I_{\mathrm{ami}}$, the intracellular electrodes were withdrawn and the oocyte was placed for $5 \mathrm{~min}$ in ND96 to recover from the impalement and to reseal the plasma membrane [26]. Subsequently, the oocyte was transferred to $150 \mu \mathrm{L}$ of protease-supplemented ND96, containing wild-type FSAP-SPD (FSAP-SPD-WT) or the inactive Marburg I variant of FSAP-SPD (FSAP-SPD-MI), or $150 \mu \mathrm{l}$ of protease-free ND96 as a control. Unless stated otherwise, oocytes were incubated for $30 \mathrm{~min}$ before a second measurement of $\Delta I_{\mathrm{ami}}$ was performed.

\section{Western blot from kidney tissue of mice}

Western blot analysis of $\alpha-, \beta-$, and $\gamma$-ENaC expression was performed from a membrane protein preparation of kidney cortex collected under control condition or on the 7th day after induction of nephrotic syndrome when urinary sodium retention concentration dropped below $20 \mathrm{mM}$, indicating maximal $\mathrm{ENaC}$ activation. Half the kidney per mouse was sliced, and the cortex was dissected using a scalpel. Homogenization was performed using a Dounce homogenizer in $1 \mathrm{ml}$ lysis buffer containing $250 \mathrm{mM}$ sucrose, $10 \mathrm{mM}$ triethanolamine $\mathrm{HCl}, 1.6 \mathrm{mM}$ ethanolamine, and 0.5 EDTA at $\mathrm{pH}$ 7.4 (all Sigma) [42]. During all preparation steps, aprotinin $\left(40 \mu \mathrm{g}^{-1}\right)$ and a protease inhibitor cocktail (final concentration $0.1 \times$ stock; mini-complete, Roche) were present to avoid $\mathrm{ENaC}$ cleavage in vitro. Homogenates were centrifuged at $1000 \mathrm{~g}$ for removal of the nuclei. Subsequently, the supernatant was centrifuged at $20,000 \mathrm{~g}$ for $30 \mathrm{~min}$ at $4{ }^{\circ} \mathrm{C}$, and the resulting pellet containing plasma membranes was resuspended and diluted to a concentration of $5 \mathrm{mg} \mathrm{L}^{-1}$. For analysis of $\gamma$-ENaC expression, samples were deglycosylated using PNGaseF according to the manufacturer's instructions (NEB, Ipswich, USA) and as previously described [7, 16]. First, samples were denaturated with a glycoprotein denaturing buffer. Samples were then incubated with glycobuffer, NP-40, and PNGaseF for $1 \mathrm{~h}$ at $37^{\circ} \mathrm{C}$. For the analysis of $\alpha$ - and $\beta-\mathrm{ENaC}$, native samples without deglycosylation were boiled in Laemmli buffer at $70{ }^{\circ} \mathrm{C}$ for $10 \mathrm{~min}$. Subsequently, $20 \mu \mathrm{g}$ of sample was loaded on an $8 \%(\gamma$-ENaC) or $4^{-1} 5 \%$ ( $\alpha$ - and $\beta$-ENaC) polyacrylamide gel for electrophoresis under reducing conditions. After transfer of the proteins onto a nitrocellulose membrane (Amersham, UK), the blocked blots were incubated with primary rabbit antibodies against murine $\alpha$-, $\beta$ - (custom-made, Pineda, Berlin), and $\gamma$-ENaC (SPC-403, Stressmarq, Viktoria, Canada) overnight at $4{ }^{\circ} \mathrm{C}$ after $1: 1000$ dilution in blocking buffer (Licor, Lincoln, USA) [4, 14, 28]. Antibodies were based on the peptide sequences described by Masilamani et al. [27] and validated using lysates from oocytes expressing murine $\alpha \beta \gamma \mathrm{ENaC}$ against lysates from sham-injected oocytes as described previously [7]. Signals were detected using fluorescent secondary antibody labeled with IRDye $800 \mathrm{CW}$ or IRDye 680RD and a fluorescence scanner (Licor Odyssey, Lincoln, USA). After detection of $\alpha-\mathrm{ENaC}$, the membranes were stripped for detection of $\beta$-ENaC according to the manufacturer's instruction using the NewBlot Nitro Stripping Buffer (Licor, Lincoln, USA). For loading control, total protein was measured using Revert Total Protein Stain (Licor, Lincoln, USA). For densitometry, ENaC signals were normalized for total protein signal of the entire lane using Image Studio version 3.1.4 and Empiria Studio version 1.3.0.83 (Licor, Lincoln, USA).

\section{Statistical analysis}

Data are provided as arithmetic means with SEM. Data were tested for normality with the Kolmogorov-Smirnov test, D'Agostino and Pearson omnibus normality test, and Shapiro-Wilk test. Differences between healthy and nephrotic groups were tested for significance using $t$-test or Wilcoxon rank sum test. Densitometry from western blot was analyzed by a two-way ANOVA with state (healthy vs. nephrotic) and genotype $\left(H a b p 2^{+/+}\right.$vs. Habp $\left.2^{-/-}\right)$as variables. Electrophysiological data were assessed by one-way ANOVA with Bonferroni post hoc test or paired $t$-test, as indicated in corresponding figure legends. A $p$-value $<0.05$ was considered as statistically significant. Mouse and electrophysiological data were analyzed using GraphPad Prism (GraphPad Software, La Jolla, CA, USA, www.graphpad.com).

\section{Results}

\section{Active FSAP is present in the urine of nephrotic patients and mice}

In urine samples from healthy persons, FSAP was not detected by Western blot analysis under non-reducing conditions (Fig. 1a). In contrast, urine from nephrotic patients contained FSAP as single chain $(64 \mathrm{kDa})$ representing the zymogen form as well as the FSAP inhibitor complex $(\sim 150 \mathrm{kDa}$; Fig. 1a). The identity of these SDSstable protease inhibitor complexes was not investigated further. Under reducing conditions using two antibodies, 


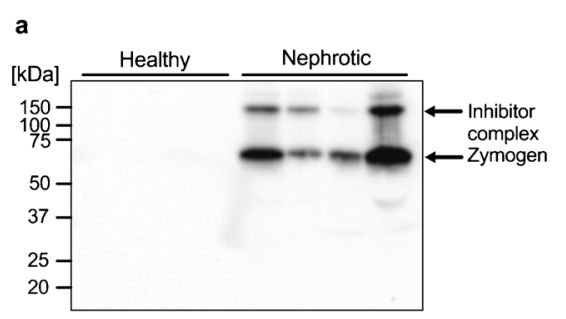

\section{b}
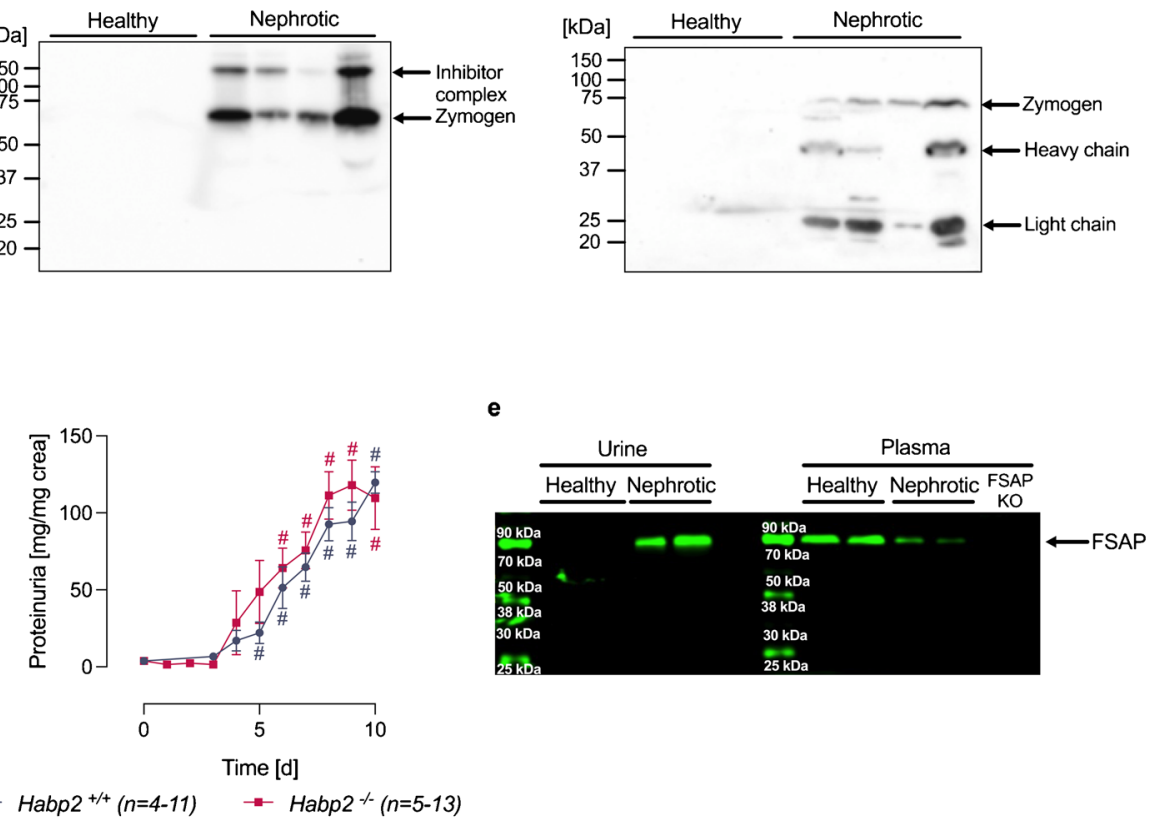
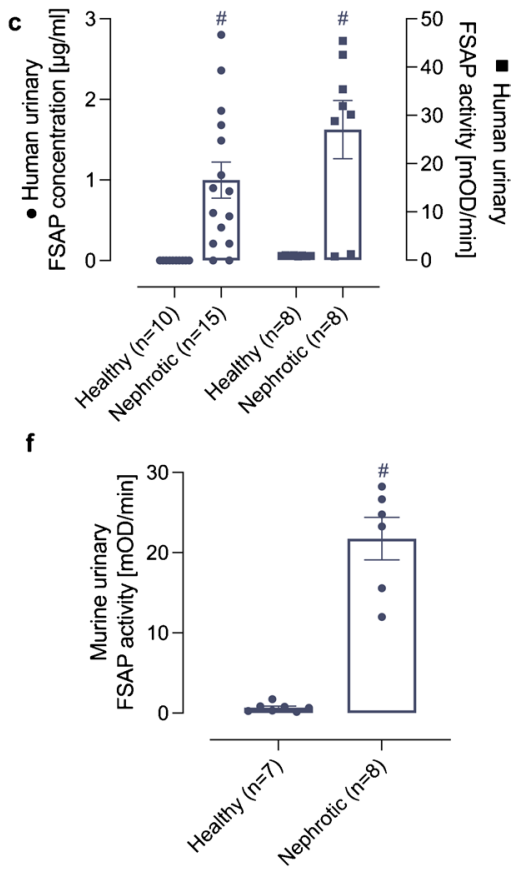

Fig. 1 Urinary excretion of FSAP in nephrotic syndrome. a Western blot from human urine samples ( $n=4$ healthy, $n=4$ nephrotic) under non-reducing conditions using a rabbit polyclonal antibody. In nephrotic samples, FSAP is detected at $64 \mathrm{kDa}$ as zymogen and at $150 \mathrm{kDa}$ as part of a inhibitor complex. b Western blot of the same samples ( $n=4$ healthy, $n=4$ nephrotic) as used in (A) under reducing conditions using a mix of two monoclonal antibodies. In addition to the detection of FSAP zymogen as single chain $(64 \mathrm{kDa})$, both the light $(27 \mathrm{kDa})$ and heavy chain $(50 \mathrm{kDa})$ are detected which requires previous cleavage at the activation bond R311. Both chains dissociate under reducing conditions. c Quantitation of urinary FSAP concentration and activity in human nephrotic urine samples. Activity was measured with pro-uPA as substrate after immunocapture of

FSAP was detected as the single chain zymogen form and in its two-chain form consisting of a light chain carrying the serine protease domain $(27 \mathrm{kDa})$ and the heavy chain (50 kDa) (Fig. 1b). This finding indicates activation of FSAP by cleavage at the activation site, R311, and dissociation of both chains under reducing conditions. Proteolytic activation of FSAP was confirmed in an activity assay with pro-uPA as substrate, which detected active FSAP in nephrotic urine (Fig. 1c). Since this activity assay is based on the immunocapture of FSAP from the plasma, it is very specific for FSAP. The urinary concentration of FSAP in urine of nephrotic patients was variable and ranged from 0 to $2.8 \mu \mathrm{g} \mathrm{mL}^{-1}$ (Fig. 1c).

The presence of FSAP was also investigated in a mouse model of doxorubicin-induced nephrotic syndrome in $\mathrm{Hapb2}^{+/+}$and $\mathrm{Hapb2} 2^{-/-}$mice. Proteinuria was similar in both genotypes (Fig. 1d). In Western blot analysis of urine samples from healthy Habp $2^{+/+}$mice, FSAP was not detectable (Fig. 1e). In contrast, in urine samples from nephrotic $H a b p 2^{+/+}$mice, FSAP appeared with an identical size as in
FSAP. Results are quantified as uPA chromogenic substrate turnover in $\mathrm{mOD} \mathrm{min}^{-1}$. d Proteinuria in wildtype $\left(\mathrm{Habp}^{+/+}\right)$and FSAPdeficient mice $\left(\mathrm{Habp2}^{-/-}\right)$after induction of experimental nephrotic syndrome by doxorubicin. e Western blot for FSAP expression from plasma and urine of $\mathrm{Habp2}^{+/+}$mice $(n=2)$. FSAP is detected at $64 \mathrm{kDa}$ in its zymogen form in plasma samples and nephrotic urine. Compared to healthy plasma, FSAP expression appears to be reduced most likely due to urinary loss. The antibody does not recognize this band in the plasma from $\mathrm{Habp}^{-/-}$mice proving the specificity of the antibody. f FSAP activity in mouse urine from $\mathrm{Habp} 2^{+/+}$mice as determined with pro-uPA as substrate. Results are quantified as uPA chromogenic substrate turnover in $\mathrm{mOD} \mathrm{min}^{-1}$. \#Significant difference between healthy and nephrotic samples

plasma (64 kDa; Fig. 1e). The antibody for detecting mouse FSAP is not capable of detecting reduced FSAP; hence, it was not possible to determine whether the FSAP was in a single chain or two-chain from. The plasma levels of FSAP were decreased in nephrotic mice which is consistent with its excretion in the urine. No FSAP was detected in $\mathrm{Habp}^{-/-}$mouse plasma (Fig. 1e). Using the activity assay with pro-uPA as substrate, active FSAP was detected in the urine of nephrotic $\mathrm{Habp}^{+/+}$mice (Fig. 1f). In conclusion, FSAP is present in human and murine nephrotic urine and is found in the active two-chain form.

\section{FSAP stimulates ENaC currents in Xenopus laevis oocytes expressing human $\mathrm{ENaC}$ by cleavage at the putative prostasin site}

FSAP has a predisposition to cleave substrates with a cluster of basic amino acids [24]. Thus, FSAP cleavage sites show a remarkable similarity with previously identified cleavage sites in $\alpha$ - and $\gamma$-ENaC $[10,13,21]$. To study whether FSAP 
may stimulate sodium transport via proteolytic $\mathrm{ENaC}$ activation, we performed two-electrode voltage clamp measurements using Xenopus laevis oocytes heterologously expressing human $\alpha \beta \gamma$-ENaC. The recombinant serine protease domain of FSAP (FSAP-SPD-WT; amino acids 292-560) has the same substrate specificity as full-length plasma FSAP [11, 29, 36]. Therefore, we used recombinant FSAP-SPD-WT for our in vitro experiments. As illustrated by representative current traces shown in Fig. 2a (left and middle panels) and summarized in Fig. 2a (right panel), incubation of ENaC expressing oocytes with FSAP-SPDWT $\left(50 \mu \mathrm{g} \mathrm{mL}^{-1}\right)$ for $30 \mathrm{~min}$ strongly stimulated amiloridesensitive whole-cell currents $\left(\Delta I_{\text {ami }}\right)$. In contrast, $\Delta I_{\text {ami }}$ remained almost unchanged, when oocytes were incubated with the same concentration of a mutant FSAP-SPD carrying the inactive Marburg mutation (FSAP-SPD-MI; Fig. 2b).
As expected, protease-free control solution had no significant effect on $\Delta I_{\text {ami }}$ (Fig. 2c). $\Delta$

We also incubated oocytes with lower $\left(1\right.$ and $10 \mu \mathrm{g} \mathrm{mL}^{-1}$ ) or higher $\left(100 \mu \mathrm{g} \mathrm{mL}^{-1}\right)$ concentrations of FSAP-SPD-WT or FSAP-SPD-MI. As shown in Fig. 2d, FSAP-SPD-WT stimulated $\mathrm{ENaC}$ in a concentration-dependent manner but with considerable variability between individual oocytes. With $100 \mu \mathrm{gL}^{-1}$, the average stimulatory effect was about fivefold and appeared to have reached a maximum. In contrast, FSAP-SPD-MI had no significant stimulatory effect on $\mathrm{ENaC}$ even when applied in a concentration of $100 \mu \mathrm{g} \mathrm{mL}^{-1}$. The stimulatory effect of proteases on $\mathrm{ENaC}$ currents is not only concentration-dependent but also time-dependent [18]. Indeed, when the incubation time was prolonged from 30 to 120 (or 240) min, the stimulatory effect of $10 \mu \mathrm{g} \mathrm{mL}-1$ of FSAP-SPD-WT on $\Delta I_{\text {ami }}$ significantly increased and reached a

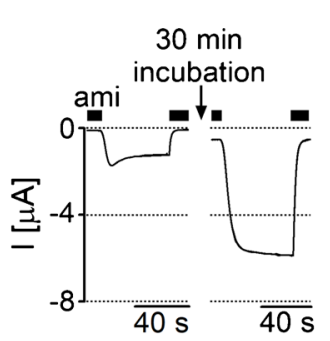

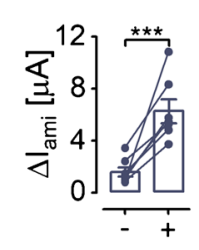

d

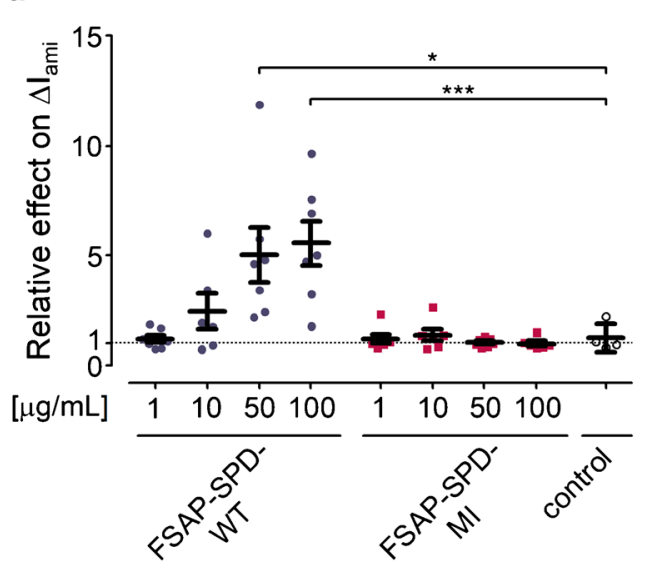

b

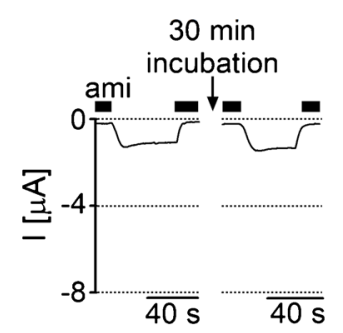

e

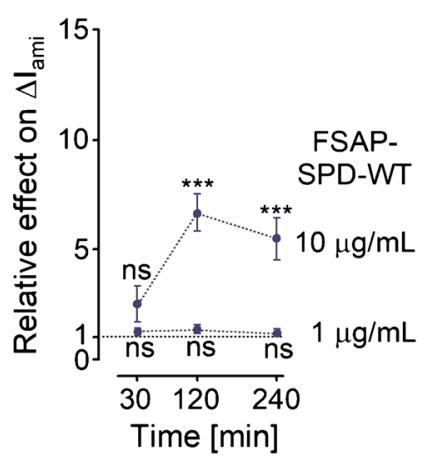

C
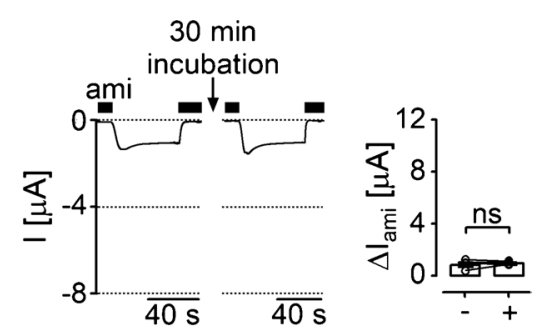

$\mathbf{f}$

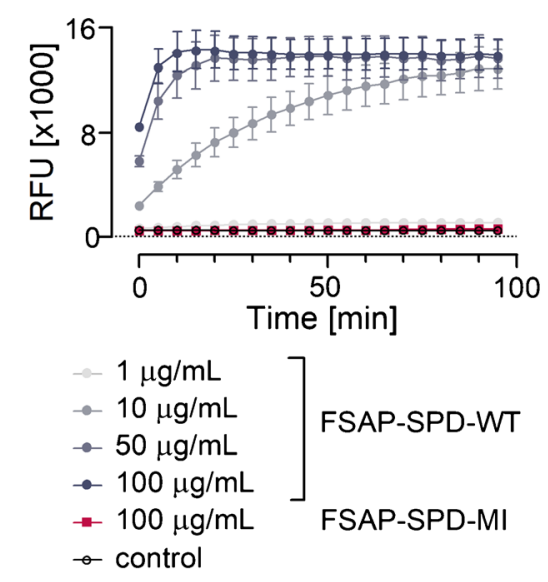

Fig. 2 Stimulation of ENaC-mediated whole-cell currents by recombinant serine protease domain of FSAP. a-c Representative wholecell current traces recorded in oocytes expressing human $\alpha \beta \gamma \mathrm{ENaC}$ before (left panels) and after (middle panels) 30-min incubation in ND96 containing FSAP-SPD-WT $\left(50 \mu \mathrm{gL}^{-1}\right.$ or $1.67 \mu \mathrm{M}$; a) or FSAP-SPD-MI $\left(50 \mu \mathrm{g} \mathrm{mL}^{-1} ; \mathbf{b}\right)$ or in protease-free ND96 (control; c). Data obtained from similar experiments as shown in left and middle panels are summarized in corresponding right panels. Amiloride-sensitive currents $\left(\Delta I_{\text {ami }}\right)$ were determined before $(-)$ and after $(+)$ incubation with FSAP-SPD-WT (a), FSAP-SPD-MI (b), or control solution (c). Measurements performed in the same oocyte are connected by a line $(n=4-7)$. d Summary of data from the same experiments as shown in $\mathbf{a}-\mathbf{c}$ and from additional experiments in which different pro- tease concentrations were used as indicated. Incubation time (30 min) was the same in all experiments. The relative effect on $\Delta I_{\text {ami }}$ was calculated for each oocyte as the ratio of $\Delta I_{\text {ami }}$ measured after and before the incubation period $(n=4-7)$. Each data point corresponds to one individual oocyte. e Effect of $1(0.03 \mu \mathrm{M})$ or $10 \mu \mathrm{g} \mathrm{mL}^{-1}(0.33 \mu \mathrm{M})$ FSAP-SPD-WT on $\Delta I_{\text {ami }}$ for different incubation times $(30,120$, or $240 \mathrm{~min}$ ). Significance is indicated for comparison with baseline $\Delta I_{\text {ami }}$ measured before incubation with the protease $(n=5-7)$. $\mathbf{f}$ Time course of proteolytic activity in the indicated incubation solutions detected using the fluorogenic substrate Boc-QAR-AMC (RFU = relative fluorescence unit; $n=10-11)$. ${ }^{*} p<0.05 ; \dagger p<0.01$; ns non-significant; paired $t$-test $(\mathbf{a}-\mathbf{c}, \mathbf{e})$ or one-way ANOVA with Bonferroni post hoc test (d). Error bars, S.E 
a similar level as observed with higher FSAP-SPD-WT concentrations (50 or $100 \mu \mathrm{g} \mathrm{mL}^{-1}$ ) and an incubation time of only $30 \mathrm{~min}$ (Fig. 2e). In contrast, no significant stimulation was observed with $1 \mu \mathrm{g} \mathrm{mL}^{-1}$ of FSAP-SPD-WT even after 240 min of incubation. The observed time- and concentration-dependence of the stimulatory effect of FSAP-SPD-WT on $\Delta I_{\text {ami }}$ corresponded well with the time- and concentration-dependence of its proteolytic activity measured using a fluorogenic substrate assay (Fig. 2f).

The stimulatory effect of FSAP on $\Delta I_{\text {ami }}$ is likely due to proteolytic $\mathrm{ENaC}$ activation involving the putative prostasin site in the $\gamma$-subunit of the channel as previously shown for other serine proteases like plasma kallikrein [19] and plasmin [18]. To identify the contribution of this site to the stimulatory effect of FSAP on ENaC, we co-expressed wildtype $\alpha$ - and $\beta$-ENaC together with a $\gamma$-ENaC subunit mutated at the putative prostasin cleavage site ( $\gamma$ RKRK178AAAA). In parallel control experiments, we confirmed that wild-type $\mathrm{ENaC}$ was strongly stimulated by FSAP-SPD-WT by about fivefold (Fig. 3a, c, d). In contrast, in oocytes expressing the mutant ENaC, the effect of FSAP-SPD-WT on $\Delta I_{\text {ami }}$ was largely abolished (Fig. 3b, c, d) and not significantly different from that of protease-free control solution on wild-type or mutant $\mathrm{ENaC}$ (Fig. 3c, d). These data indicate that proteolytic $\mathrm{ENaC}$ activation by FSAP requires an intact prostasin cleavage site in the channel's $\gamma$-subunit.

\section{Mice lacking FSAP $\left(\mathrm{Habp2}^{-/-}\right)$are not protected from sodium retention in experimental nephrotic syndrome.}

To determine whether FSAP participates in ENaC-mediated sodium retention in vivo, we studied the course of experimental nephrotic syndrome in mice lacking FSAP $\left(\mathrm{Habp}^{-/-}\right)$and their wildtype littermates $\left(\mathrm{Habp}^{+/+}\right)$. Following doxorubicin injection, Habp $2^{-/-}$mice developed similar proteinuria (Fig. 1e) as $\mathrm{Habp2}^{+/+}$mice. The natriuretic response to amiloride $\left(10 \mu \mathrm{g} \cdot \mathrm{g} \mathrm{bw}^{-1}\right.$ i.p.) was determined to assess ENaC activity in healthy Habp2 $2^{+/+}$ and $\mathrm{Habp}^{-/-}$mice. Baseline natriuresis was determined a

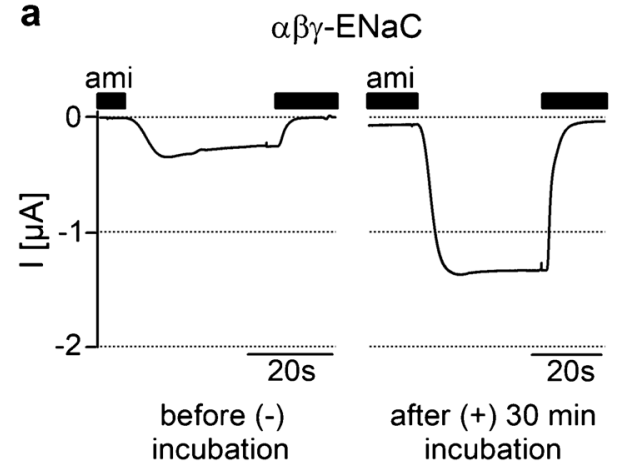

b $\quad \alpha \beta \gamma$ RKRK178AAAA-ENaC

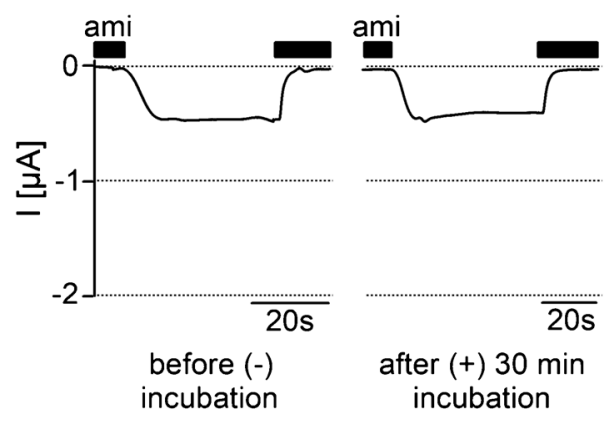

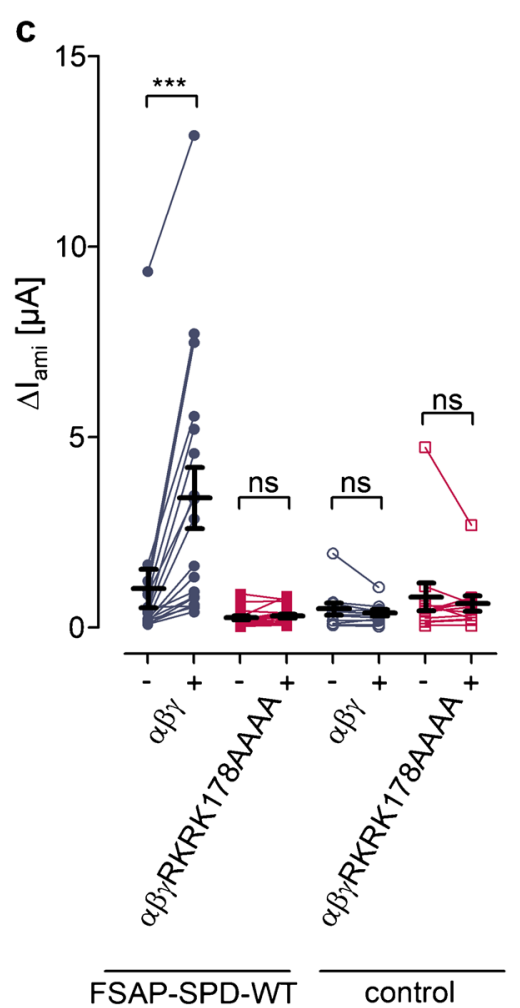

Fig. 3 Mutation of $\mathrm{ENaC}$ at its putative prostasin cleavage site prevents its proteolytic activation by recombinant serine protease domain of FSAP. a, b Representative whole-cell current traces recorded in oocytes expressing human wild-type $\mathrm{ENaC}(\alpha \beta \gamma$-ENaC; a) or coexpressing wild-type $\alpha$ - and $\beta$-ENaC with mutant $\gamma$-ENaC $(\alpha \beta \gamma R K R K 178$ AAAA-ENaC; b) before (left panels) and after (right panels) $30 \mathrm{~min}$ incubation in a solution containing FSAP-SPD-WT $\left(20 \mu \mathrm{g} \mathrm{m}^{-1}\right)$. c Summary of data obtained from similar experiments as shown in $\mathbf{a}, \mathbf{b}$ and from additional experiments in which protease-

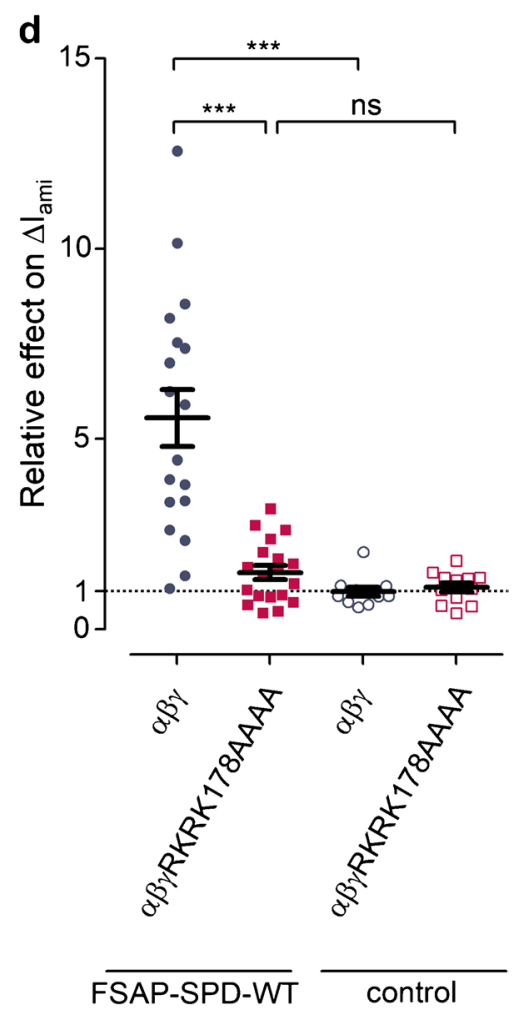

free ND96 was used as control. $\Delta I_{\text {ami }}$ was determined before $(-)$ and after (+) incubation in the indicated incubation solution. Measurements performed in the same oocyte are connected by a line $(N=2-3$, $n=11-19)$. d Summary of the same data as shown in c normalized as relative effect of the indicated incubation solution on $\Delta I_{\text {ami }}(N=2-3$, $n=11-19) . \ddagger p<0.001$; ns non-significant; paired $t$-test (c) or one-way ANOVA with Bonferroni post hoc test (d). Error bars, S.E. $N$ indicates the number of different batches of oocytes; $n$ indicates the numbers of individual oocytes measured 

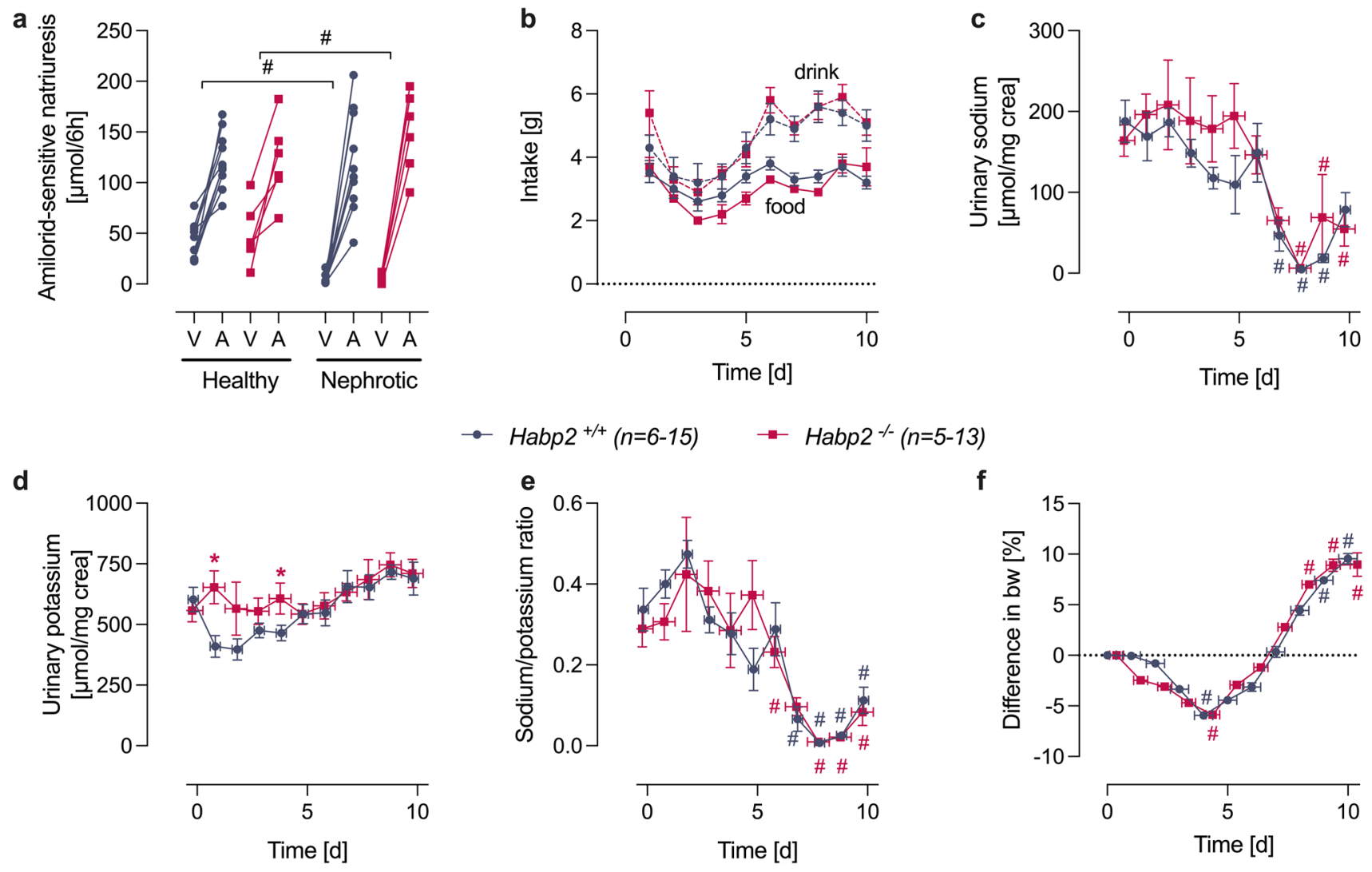

- Habp $^{+/+}(n=6-15) \rightarrow H a b p 2 \%(n=5-13)$

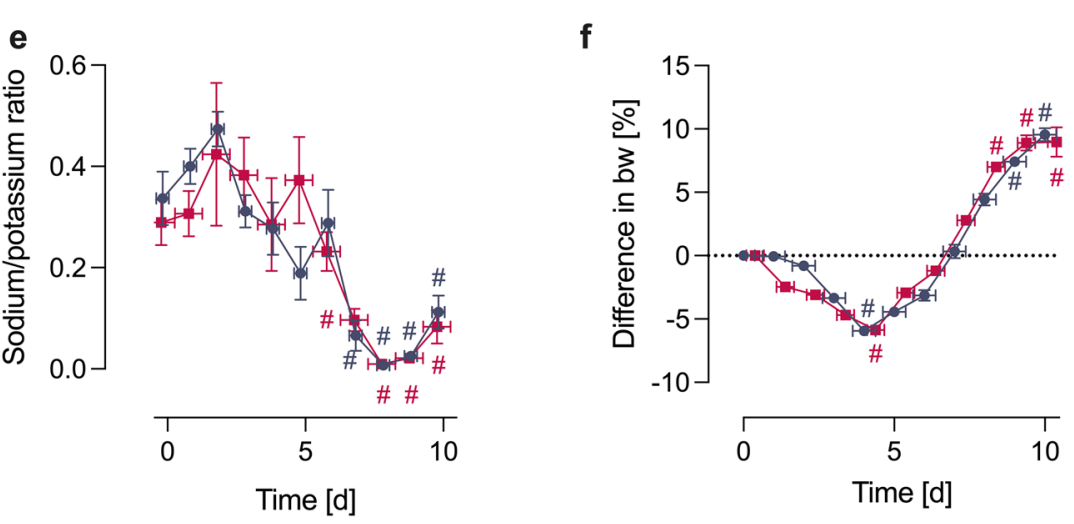

Fig. 4 Impact of FSAP deficiency on ENaC activation and sodium retention in experimental nephrotic syndrome. a Natriuretic response to vehicle (injectable water, $\left.5 \mu \mathrm{g} \mathrm{g}^{-1} \mathrm{bw}\right)$ or amiloride $\left(10 \mu \mathrm{g} \mathrm{g}^{-1} \mathrm{bw}\right.$ i.p.) in healthy and nephrotic Habp2 $2^{+/+}$and Habp2 $2^{-/-}$mice. Urine was collected for $6 \mathrm{~h}$ after injection and all mice underwent vehicle and amiloride injection sequentially (at day $-14 /-13$ and day $7 / 8$, respectively). b-f Course of food and fluid intake, urinary sodium and potassium excretion and its ratio in spot urine samples and body

from injection of vehicle (injectable water, $5 \mu \mathrm{l} \cdot \mathrm{g} \mathrm{bw}^{-1}$ i.p.). As shown in Fig. 4a, this response was similar in healthy $\mathrm{Habp}^{+/+}$and Habp2 ${ }^{-/-}$mice. The calculated ratio of natriuresis after vehicle and amiloride injection corresponding to the slope in Fig. $4 \mathrm{a}$ was $3.4 \pm 0.6$ and $4.0 \pm 1.7$ in healthy $\mathrm{Habp2}^{+/+}$and Habp2 $2^{-/-}$mice, respectively, indicating similar $\mathrm{ENaC}$ function in both genotypes. After induction of nephrotic syndrome, this ratio increased significantly in both genotypes to $53 \pm 13$ and $46 \pm 21$ in nephrotic $\mathrm{Habp2}^{+/+}$and $\mathrm{Habp}^{-/-}$mice, respectively, without a significant difference between the genotypes $(p=0.49)$. Studies of sodium balance revealed that $\mathrm{Habp}^{+/+}$and $H a b p 2^{-/-}$mice developed renal sodium retention after induction of nephrotic syndrome (Table 1). During the course of nephrotic syndrome daily urinary sodium concentration dropped to minimal values of $5 \pm 1 \mu \mathrm{mol} \mathrm{mg}{ }^{-1}$ creatinine and $6 \pm 1 \mu \mathrm{mol} \mathrm{mg} \mathrm{m}^{-1}$ creatinine in $\mathrm{Habp}^{+/+}$and $\mathrm{Habp}^{-/-}$mice, respectively, despite constant food and fluid intake (Fig. $4 \mathrm{~b}-\mathrm{c}$ ), urinary potassium excretion was not altered appreciably (Fig. 4d). Urinary weight taken in the morning after induction of nephrotic syndrome in $\mathrm{Habp}^{+/+}$and $\mathrm{Habp}^{-/-}$mice. Note: Due to a variance of one day in the onset of proteolytic ENaC activation in experimental nephrotic syndrome, the data in $\mathbf{c}-\mathbf{e}$ were fit to the day of lowest urinary sodium (day 8) and to the day of lowest bodyweight (day 4) (f), which results in an $\mathrm{x}$ error depicted in the corresponding graphs. \#Significant difference between healthy and nephrotic state. *Significant difference between the genotypes

sodium/potassium ratio was decreased in nephrotic mice of both genotypes indicating tubular sodium avidity (Fig. 4e). Subsequently, nephrotic mice gained body weight and developed ascites indicating sodium retention in both genotypes (Fig. 4f). The maximal body weight gain calculated from the difference of the body weight between day 4 and day 10 was $18 \pm 1 \%$ and $21 \pm 2 \%$ in $\mathrm{Habp}^{+/+}$and $\mathrm{Habp}^{-/-}$mice, respectively, which was not significantly different $(p=0.23)$.

Table 2 depicts the plasma concentrations of urea, albu$\mathrm{min}$, electrolytes, hemoglobin, and $\mathrm{pH}$. There were no significant differences in any parameter in healthy $\mathrm{Habp2}^{+/+}$and $\mathrm{Habp}^{-/-}$mice. Plasma potassium concentrations were significantly increased compared to baseline in both genotypes. There was no difference between the genotypes (Table 2). In nephrotic mice, there was a marked decrease in plasma albumin concentration indicating negative albumin balance and a tendency towards increased plasma urea concentration pointing to a mild decrease of GFR. In nephrotic Habp2 $2^{+/+}$ mice, plasma $\mathrm{Na}^{+}$and hemoglobin concentration as well as 
hematocrit were decreased, consistent with dilution of the plasma volume. This finding was less prominent in nephrotic Habp $^{-1-}$ mice.

\section{Expression of ENaC subunits and proteolytic activation of ENaC in nephrotic $\mathrm{Habp2}^{+/+}$ and Habp2 ${ }^{-/-}$mice.}

Western blot analyses from kidney cortex revealed two bands for $\alpha-\mathrm{ENaC}$ at 82 and $25 \mathrm{kDa}$ representing full-length and a cleavage product, most probably after distal cleavage (designated from the N-terminus; Fig. 5a, b). For $\gamma$-ENaC, three bands were detected in PNGase-treated samples at 66, 56, and $49 \mathrm{kDa}$ representing full-length, proximally and distally cleaved fragments, respectively (Fig. 5c) [7, 16]. Specificity of these bands was confirmed by application of the immunogenic peptide and oocytes expressing murine $\alpha \beta \gamma \mathrm{ENaC}$ as shown elsewhere [7]. For $\beta$-ENaC, there was only a single band at $84 \mathrm{kDa}$ corresponding to the full-length subunit which is not proteolytically processed. In healthy $\mathrm{Habp}^{+/+}$ and $H a b p 2^{-l-}$ mice, there was no significant difference in the expression of any $\mathrm{ENaC}$ subunit. After induction of nephrotic syndrome, there was a significant increase of the expression of full-length $\alpha$-ENaC, whereas the expression of full-length $\beta$ - and $\gamma$-ENaC was not altered in both genotypes (Fig. 5d, f, g). In nephrotic Habp2 $2^{+/+}$and Habp2 $2^{-/-}$mice, the expression of the cleavage fragments of $\alpha$-ENaC at 25 and of $\gamma$-ENaC at 56 and $49 \mathrm{kDa}$, respectively, were found to be significantly increased, indicating proteolytic $\mathrm{ENaC}$ activation at both subunits (Fig. 5e, h, i). However, there was no difference between the genotypes.

\section{Discussion}

Our study reveals three novel findings: first, it demonstrates that FSAP is excreted in the urine of nephrotic patients and mice with kidney disease as a zymogen and as active protease. Secondly, FSAP was shown to stimulate ENaC currents in vitro through proteolysis of $\gamma-\mathrm{ENaC}$ at the putative prostasin cleavage site ( $\gamma$ RKRK178). The stimulatory effect of FSAP on ENaC activity was prevented by mutating this cleavage site. Thirdly, nephrotic mice with FSAP deficiency were not protected from sodium retention and proteolytic $\mathrm{ENaC}$ activation. This latter finding indicates that FSAP is not essential for mediating sodium retention and that other serine proteases or mechanisms cause proteolytic $\mathrm{ENaC}$
Table 1 Sodium balance under a sodium replete control diet in $\mathrm{Habp2}^{+/+}$and $\mathrm{Habp2}^{-1-}$ mice before and on day 7 of experimental nephrotic syndrome.

\begin{tabular}{|c|c|c|c|c|}
\hline & Healthy & & Nephrotic & \\
\hline & $H a b p 2^{+/+}$ & Habp2 $2^{-l-}$ & Habp $2^{+/+}$ & $H a b p 2^{-/-}$ \\
\hline Total $\mathrm{Na}^{+}$intake, $\mu \mathrm{mol} 24 \mathrm{~h}^{-1}$ & $245 \pm 26$ & $265 \pm 38$ & $291 \pm 38$ & $261 \pm 39$ \\
\hline Urinary $\mathrm{Na}^{+}$excretion, $\mu \mathrm{mol} 24 \mathrm{~h}^{-1}$ & $103 \pm 22$ & $108 \pm 13$ & $12 \pm 4 \#$ & $10 \pm 3 \#$ \\
\hline Fecal $\mathrm{Na}^{+}$excretion, $\mu \mathrm{mol} 24 \mathrm{~h}^{-1}$ & $24 \pm 4$ & $37 \pm 4^{*}$ & $13 \pm 3 \#$ & $11 \pm 1 \#$ \\
\hline $\mathrm{Na}^{+}$balance, $\mu$ mol $24 \mathrm{~h}^{-1}$ & $118 \pm 22$ & $120 \pm 33$ & $266 \pm 36 \#$ & $239 \pm 37 \#$ \\
\hline
\end{tabular}

Arithmetic means \pm SEM ( $n=6$ each). Note that the body weight was similar in $\mathrm{Habp}^{+/+}$and $\mathrm{Habp2}^{-/-}$ mice $(25.6 \pm 0.9 \mathrm{~g}$ vs. $24.7 \pm 1.3 \mathrm{~g}, p=0.59)$. \#Significant difference between healthy and nephrotic mice; *significant difference between genotypes

\begin{tabular}{lllll}
\hline & Healthy & & Nephrotic \\
\hline & Habp2 2/+ & Habp2 $^{-/-}$ & Habp2 $^{+/+}$ & Habp2 \\
$\mathrm{pH}$ & $7.24 \pm 0.2$ & $7.30 \pm 0.01$ & $7.29 \pm 0.02$ & $7.32 \pm 0.02$ \\
$\mathrm{std} \mathrm{HCO}_{3}^{--}, \mathrm{mM}$ & $22 \pm 0.4$ & $21 \pm 1$ & $24 \pm 1$ & $25 \pm 2$ \\
$\mathrm{Na}^{+}, \mathrm{mM}$ & $147 \pm 0.4$ & $147 \pm 1$ & $139 \pm 2 \#$ & $143 \pm 2$ \\
$\mathrm{~K}^{+}, \mathrm{mM}$ & $4.4 \pm 0.1$ & $4.2 . \pm 0.1$ & $5.8 \pm 0.2 \#$ & $5.7 \pm 0.4 \#$ \\
$\mathrm{Ca}^{++}, \mathrm{mM}$ & $1.09 \pm 0.01$ & $1.06 \pm 0.02$ & $1.11 \pm 0.02$ & $1.09 \pm 0.05$ \\
$\mathrm{Hct}, \%$ & $44.3 \pm 0.7$ & $43.7 \pm 0.8$ & $37.2 \pm 2.5 \#$ & $43.7 \pm 1.7$ \\
$\mathrm{cHbc}, \mathrm{g} \mathrm{dL}^{-1}$ & $14.6 \pm 0.2$ & $14.4 \pm 0.2$ & $12.3 \pm 0.8$ & $14.5 \pm 0.6$ \\
urea, mg dL & $51 \pm 7$ & $39 \pm 3$ & $58 \pm 15$ & $78 \pm 28$ \\
albumin, $\mathrm{g} \mathrm{L}^{-1}$ & $34 \pm 2$ & $35 \pm 2$ & $12 \pm 1 \#$ & $13 \pm 2 \#$ \\
\hline
\end{tabular}

Arithmetic means \pm SEM. Parameters from venous blood gas analysis were determined in $n=7-9$ mice per group. Plasma urea and albumin concentration was determined in $n=4$ mice per group. \#Significant difference between healthy and nephrotic state; Abbreviations: std standard, Hct hematocrit, cHbc calculated hemoglobin concentration
Table 2 Plasma parameters of healthy and nephrotic $\mathrm{Habp}^{+/+}$ and $\mathrm{Habp}^{-1-}$ mice before and on day 10 of experimental nephrotic syndrome. 


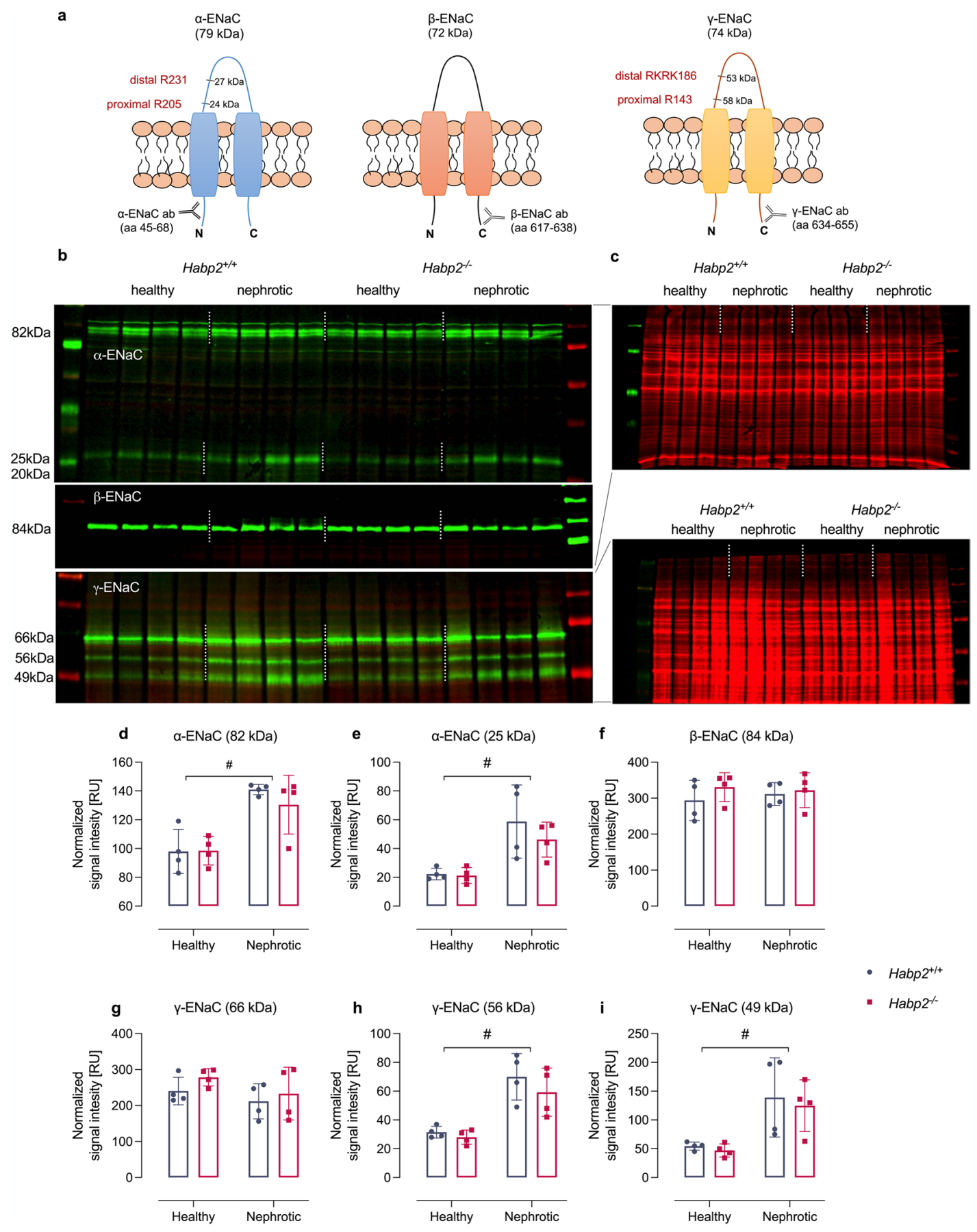

Fig. 5 Renal expression of ENaC subunits in experimental nephrotic syndrome. a Localization of the immunogenic sequences of the used antibodies against murine $\alpha-, \beta$-, and $\gamma$-ENaC. In $\alpha$ - and $\gamma$-ENaC, the proximal and distal cleavage sites (designated from the $\mathrm{N}$-terminus, respectively) are depicted. The antibody against $\mathrm{N}$-terminal $\alpha$-ENaC is supposed to detect full-length $\alpha$-ENaC at $79 \mathrm{kDa}(699 \mathrm{aa})$ and two N-terminal fragments with a mass of $27 \mathrm{kDa}(231 \mathrm{aa})$ and $24 \mathrm{kDa}(205 \mathrm{aa})$. The antibody against C-terminal $\beta$-ENaC is supposed to detect full-length $\beta$-ENaC at $72 \mathrm{kDa}(638 \mathrm{aa})$. The antibody against C-terminal $\gamma$-ENaC is supposed to detect full-length $\gamma$-ENaC at $74 \mathrm{kDa}(655 \mathrm{aa})$ and $\mathrm{C}$-terminal fragments with a mass of $58 \mathrm{kDa}$ (512 aa) after proximal cleavage and at $53 \mathrm{kDa}$ (469 aa) after distal cleavage, respectively. Mass values are calculated from the amino acid sequences (omitting any $\mathrm{N}$-glycosylations). b Western blots showing the expression of ENaC subunits in a plasma membrane preparation of kidney cortex from $\mathrm{Habp}^{+/+}$and $\mathrm{Habp}^{-/-}$mice. $\alpha$ and $\beta$-ENaC expression were analyzed in native samples on a $4-15 \%$ gradient gel after stripping, $\gamma$-ENaC expression was analyzed after deglycosylation of the same samples on an $8 \%$ gel. The higher molecular mass for $\alpha$ - and $\beta$-ENaC stems from $\mathrm{N}$-glycosylation. c Total protein stain for control of loading and blotting. $\mathbf{d}-\mathbf{i}$ Densitometry of the obtained bands normalized for total protein content of each lane $(n=4$ each). " Significant difference between healthy and nephrotic state (two-way ANOVA) 
activation and sodium retention in this model of nephrotic syndrome.

Interestingly, we detected active FSAP in urine samples of both nephrotic patients and mice in contrast to the plasma compartment where FSAP circulates as zymogen [41]. These concentrations were up to $25 \%$ of the plasma FSAP concentration of healthy humans. This raises the question how FSAP is activated in the tubule lumen after aberrant filtration. In the plasma, FSAP is mainly activated by free histones [41]. To date, there are not many studies that report the presence of histones in urine. In one study, histones related to the formation of neutrophil extracellular traps (NET) or NETosis were detected in the urine [43]. It is plausible that injury to the tubules causes the release of nucleosomes into the urine where the resident DNase cleaves the DNA to free the histones [32]. The involvement of specific urine-related factors in the activation of FSAP zymogen is also a possibility. Compared to plasma, nephrotic urine might contain lower levels of plasma protease inhibitors that will decrease the threshold for auto-activation of FSAP. Apart from cleavage of $\mathrm{ENaC}$, there are other potential substrates of FSAP in the kidney tubules such as protease activated receptors [12]. These G-protein receptors could regulate other aspects of nephrotic syndrome, e.g., inflammation, which was not investigated in the current study [30].

To our knowledge, this is the first report that the serine protease FSAP activates $\mathrm{ENaC}$. This effect was observed with $10 \mu \mathrm{g} \cdot \mathrm{mL}^{-1}$ of the recombinant SPD domain of FSAP which is higher than the concentration of FSAP in nephrotic urine (up to $2.8 \mu \mathrm{g} \cdot \mathrm{mL}^{-1}$ ). It should be noted that not all the recombinant protease is in an active form as we have reported before [29]. In mice, urinary FSAP concentration might easily exceed the concentrations observed in humans as mouse urine has a much higher solute concentration. For example, in doxorubicin-injected nephrotic mice, we found urinary plasminogen concentrations that were at least 100-fold higher than that found in nephrotic humans (>100 $\mu \mathrm{g} \mathrm{mL}^{-1}$ vs. $1 \mu \mathrm{g} \mathrm{mL}^{-1}$; $[8,37]$ ). Therefore, FSAP concentration found in nephrotic urine might be sufficiently high to activate $\mathrm{ENaC}$ in vivo.

The results further indicate that FSAP activates $\mathrm{ENaC}$ by proteolytic cleavage of its $\gamma$-subunit at the putative prostasin site $\gamma$ RKRK178, which is important for proteolytic activation of $\mathrm{ENaC}[10,13,18,19]$. Mutation of this site abolished proteolytic activation by FSAP. The prostasin cleavage site is in perfect agreement of the substrate specificity of FSAP with a preference for basic amino acids R and K [24]. Previously, we reported that plasma kallikrein and plasmin can also activate $\mathrm{ENaC}$ by cleavage at the putative prostasin site $[18,19]$. These findings underscore the importance of this cleavage site which represents a preferential site for trypsin-like serine proteases due to the polybasic amino acid sequence. In vivo, the decisive role of urinary serine proteases on $\mathrm{ENaC}$-mediated volume retention has recently been shown by our group [8]. In that study, aprotinin treatment of nephrotic mice abolished volume retention in a similar way as treatment with amiloride. The effect of aprotinin was replicated in a genetic mouse model of nephrotic syndrome [40] and indicates that the therapeutic effect of aprotinin is mediated at least in part by preventing proteolytic ENaC activation [7]. So far, the identity of the serine protease(s) responsible for $\mathrm{ENaC}$ activation in nephrotic syndrome remains unknown. With the present study, we can exclude that FSAP is essential for stimulating sodium retention solely, at least in this mouse model for nephrotic syndrome. However, there is still the possibility that proteolytic $\mathrm{ENaC}$ activation may occur redundantly so that the lack of one will be compensated by another serine protease.

In conclusion, we show that FSAP is detected in the urine of nephrotic patients and mice and causes proteolytic activation of $\mathrm{ENaC}$ in vitro. However, this stimulatory effect of FSAP is not essential for sodium retention in nephrotic mice and is most likely mediated by other serine proteases present in nephrotic urine capable of proteolytically activating $\mathrm{ENaC}$.

Author contribution FA, SMK, and CK conceived and designed study; FA, SMK, and CK wrote the manuscript; BNB, JCS, TS, FS, AVI, MW, DE, AJ, and NVN performed research; ALB, CK, and SH analyzed data; SMK, NVN, and ME contributed new methods or models.

Funding Open Access funding enabled and organized by Projekt DEAL. This study was supported by grants from the German Research Foundation (DFG) to FA (AR 1092/2-2) and to CK/SH (SFB 1350, project number 387509280$)$. Grant support was from the National Research Council of Norway (Grant No. 251239) to SMK.

Data Availability The data that support the findings of this study are available from the corresponding author upon reasonable request.

Code availability Not applicable.

\section{Declarations}

Ethics approval Obtained.

Consent to participate Obtained from all patients.

Consent for publication Not applicable.

Conflict of interest The authors declare no competing interests.

Open Access This article is licensed under a Creative Commons Attribution 4.0 International License, which permits use, sharing, adaptation, distribution and reproduction in any medium or format, as long as you give appropriate credit to the original author(s) and the source, provide a link to the Creative Commons licence, and indicate if changes were made. The images or other third party material in this article are included in the article's Creative Commons licence, unless indicated otherwise in a credit line to the material. If material is not included in 
the article's Creative Commons licence and your intended use is not permitted by statutory regulation or exceeds the permitted use, you will need to obtain permission directly from the copyright holder. To view a copy of this licence, visit http://creativecommons.org/licenses/by/4.0/.

\section{References}

1. Artunc F, Nasir O, Amann K, Boini KM, Haring HU, Risler T, Lang F (2008) Serum- and glucocorticoid-inducible kinase 1 in doxorubicin-induced nephrotic syndrome. Am J Physiol Renal Physiol 295:F1624-1634. https://doi.org/10.1152/ajprenal.00032. 2008

2. Artunc F, Worn M, Schork A, Bohnert BN (2019) Proteasuriathe impact of active urinary proteases on sodium retention in nephrotic syndrome. Acta Physiol (Oxf) 225:e13249. https://doi. org/10.1111/apha.13249

3. Bohnert BN, Artunc F (2018) Induction of nephrotic syndrome in mice by retrobulbar injection of doxorubicin and prevention of volume retention by sustained release aprotinin. J Vis Exp 135:e57642. https://doi.org/10.3791/57642

4. Bohnert BN, Daiminger S, Worn M, Sure F, Staudner T, Ilyaskin AV, Batbouta F, Janessa A, Schneider JC, Essigke D, Kanse S, Haerteis S, Korbmacher C, Artunc F (2019) Urokinase-type plasminogen activator ( $\mathrm{UPA}$ ) is not essential for epithelial sodium channel $(\mathrm{ENaC})$-mediated sodium retention in experimental nephrotic syndrome. Acta Physiol (Oxf) 227:e13286. https://doi. org/10.1111/apha.13286

5. Bohnert BN, Daniel C, Amann K, Voelkl J, Alesutan I, Lang F, Heyne N, Haring HU, Artunc F (2015) Impact of phosphorus restriction and vitamin D-substitution on secondary hyperparathyroidism in a proteinuric mouse model. Kidney Blood Press Res 40:153-165. https://doi.org/10.1159/000368491

6. Bohnert BN, Dorffel T, Daiminger S, Calaminus C, Aidone S, Falkenau A, Semrau A, Le MJ, Iglauer F, Artunc F (2019) Retrobulbar sinus injection of doxorubicin is more efficient than lateral tail vein injection at inducing experimental nephrotic syndrome in mice: a pilot study. Laboratory animals:23677218824382. https:// doi.org/10.1177/0023677218824382

7. Bohnert BN, Essigke D, Janessa A, Schneider JC, Wörn M, Kalo MZ, Xiao M, Kong L, Omage K, Hennenlotter J, Amend B, Birkenfeld AL, Artunc F (2021) Experimental nephrotic syndrome leads to proteolytic activation of the epithelial sodium channel $(\mathrm{ENaC})$ in the mouse kidney. Am J Physiol Renal Physiol. https:// doi.org/10.1152/ajprenal.00199.2021

8. Bohnert BN, Menacher M, Janessa A, Worn M, Schork A, Daiminger S, Kalbacher H, Haring HU, Daniel C, Amann K, Sure F, Bertog M, Haerteis S, Korbmacher C, Artunc F (2018) Aprotinin prevents proteolytic epithelial sodium channel $(\mathrm{ENaC})$ activation and volume retention in nephrotic syndrome. Kidney Int 93:159172. https://doi.org/10.1016/j.kint.2017.07.023

9. Borkham-Kamphorst E, Zimmermann HW, Gassler N, Bissels U, Bosio A, Tacke F, Weiskirchen R, Kanse SM (2013) Factor VII activating protease (FSAP) exerts anti-inflammatory and anti-fibrotic effects in liver fibrosis in mice and men. J Hepatol 58:104-111. https://doi.org/10.1016/j.jhep.2012.09.007

10. Bruns JB, Carattino MD, Sheng S, Maarouf AB, Weisz OA, Pilewski JM, Hughey RP, Kleyman TR (2007) Epithelial Na+ channels are fully activated by furin- and prostasin-dependent release of an inhibitory peptide from the gamma-subunit. J Biol Chem 282:6153-6160. https://doi.org/10.1074/jbc.M610636200
11. Byskov K, Etscheid M, Kanse SM (2020) Cellular effects of factor VII activating protease (FSAP). Thromb Res 188:74-78. https:// doi.org/10.1016/j.thromres.2020.02.010

12. Byskov K, Le Gall SM, Thiede B, Camerer E, Kanse SM (2020) Protease activated receptors (PAR)-1 and -2 mediate cellular effects of factor VII activating protease (FSAP). FASEB journal: official publication of the Federation of American Societies for Experimental Biology 34:1079-1090. https://doi.org/10.1096/fj. 201801986RR

13. Diakov A, Bera K, Mokrushina M, Krueger B, Korbmacher C (2008) Cleavage in the \{gamma $\}$-subunit of the epithelial sodium channel $(\mathrm{ENaC})$ plays an important role in the proteolytic activation of near-silent channels. J Physiol 586:4587-4608. https://doi. org/10.1113/jphysiol.2008.154435

14. Essigke D, Ilyaskin AV, Worn M, Bohnert BN, Xiao M, Daniel C, Amann K, Birkenfeld AL, Szabo R, Bugge TH, Korbmacher C, Artunc F (2021) Zymogen-locked mutant prostasin (Prss8) leads to incomplete proteolytic activation of the epithelial sodium channel $(\mathrm{ENaC})$ and severely compromises triamterene tolerance in mice. Acta physiologica (Oxford, England) e13640 https://doi. org/10.1111/apha.13640

15. Etscheid M, Muhl L, Pons D, Jukema JW, Konig H, Kanse SM (2012) The Marburg I polymorphism of factor VII activating protease is associated with low proteolytic and low pro-coagulant activity. Thromb Res 130:935-941. https://doi.org/10.1016/j. thromres.2012.07.023

16. Frindt G, Shi S, Kleyman TR, Palmer LG (2021) Cleavage state of gammaENaC in mouse and rat kidneys. Am J Physiol Renal Physiol 320:F485-F491. https://doi.org/10.1152/ajprenal.00536. 2020

17. Haerteis S, Krappitz A, Krappitz M, Murphy JE, Bertog M, Krueger B, Nacken R, Chung H, Hollenberg MD, Knecht W, Bunnett NW, Korbmacher C (2014) Proteolytic activation of the human epithelial sodium channel by trypsin IV and trypsin I involves distinct cleavage sites. J Biol Chem 289:19067-19078. https:// doi.org/10.1074/jbc.M113.538470

18. Haerteis S, Krappitz M, Diakov A, Krappitz A, Rauh R, Korbmacher C (2012) Plasmin and chymotrypsin have distinct preferences for channel activating cleavage sites in the gamma subunit of the human epithelial sodium channel. J Gen Physiol 140:375389. https://doi.org/10.1085/jgp.201110763

19. Haerteis S, Schork A, Dörffel T, Bohnert BN, Nacken R, Wörn M, Xiao M, Essigke D, Janessa A, Schmaier AH, Feener EP, Haring HU, Bertog M, Korbmacher C, Artunc F (2018) Plasma kallikrein activates the epithelial sodium channel $(\mathrm{ENaC})$ in vitro but is not essential for volume retention in nephrotic mice. Acta Physiol (Oxf) 224(1):e13060. https://doi.org/10.1111/apha.13060

20. Hinrichs GR, Jensen BL, Svenningsen P (2020) Mechanisms of sodium retention in nephrotic syndrome. Curr Opin Nephrol Hypertens 29:207-212. https://doi.org/10.1097/mnh.0000000000 000578

21. Hughey RP, Bruns JB, Kinlough CL, Harkleroad KL, Tong Q, Carattino MD, Johnson JP, Stockand JD, Kleyman TR (2004) Epithelial sodium channels are activated by furin-dependent proteolysis. J Biol Chem 279:18111-18114. https://doi.org/10.1074/ jbc.C400080200

22. Hunfeld A, Etscheid M, König H, Seitz R, Dodt J (1999) Detection of a novel plasma serine protease during purification of vitamin K-dependent coagulation factors. FEBS Lett 456:290-294. https:// doi.org/10.1016/s0014-5793(99)00959-x

23. Ilyaskin AV, Korbmacher C, Diakov A (2021) Inhibition of the epithelial sodium channel ( $\mathrm{ENaC})$ by connexin 30 involves stimulation of clathrin-mediated endocytosis. J Biol Chem 296:100404. https://doi.org/10.1016/j.jbc.2021.100404

24. Kara E, Manna D, Loset GA, Schneider EL, Craik CS, Kanse S (2017) Analysis of the substrate specificity of Factor VII 
activating protease (FSAP) and design of specific and sensitive peptide substrates. Thromb Haemost 117:1750-1760. https://doi. org/10.1160/th17-02-0081

25. Kleyman TR, Carattino MD, Hughey RP (2009) ENaC at the cutting edge: regulation of epithelial sodium channels by proteases. $\mathrm{J}$ Biol Chem 284:20447-20451. https://doi.org/10.1074/jbc.R8000 83200

26 Krappitz M, Korbmacher C, Haerteis S (2014) Demonstration of proteolytic activation of the epithelial sodium channel $(\mathrm{ENaC})$ by combining current measurements with detection of cleavage fragments. J Vis Exp JoVE. https://doi.org/10.3791/51582

27. Masilamani S, Kim GH, Mitchell C, Wade JB, Knepper MA (1999) Aldosterone-mediated regulation of ENaC alpha, beta, and gamma subunit proteins in rat kidney. $\mathrm{J}$ Clin Invest 104https://doi.org/10.1172/jci7840

28. Nesterov V, Krueger B, Bertog M, Dahlmann A, Palmisano R, Korbmacher C (2016) In Liddle syndrome, epithelial sodium channel is hyperactive mainly in the early part of the aldosterone-sensitive distal nephron. Hypertension 67:1256-1262. https://doi.org/10.1161/hypertensionaha.115.07061

29. Nielsen NV, Roedel E, Manna D, Etscheid M, Morth JP, Kanse SM (2019) Characterization of the enzymatic activity of the serine protease domain of Factor VII activating protease (FSAP). Sci Rep 9:18990. https://doi.org/10.1038/s41598-019-55531-x

30. Palygin O, Ilatovskaya DV, Staruschenko A (2016) Proteaseactivated receptors in kidney disease progression. Am J Physiol Renal Physiol 311:F1140-f1144. https://doi.org/10.1152/ajpre nal.00460.2016

31. Passero CJ, Hughey RP, Kleyman TR (2010) New role for plasmin in sodium homeostasis. Curr Opin Nephrol Hypertens 19:13-19. https://doi.org/10.1097/MNH.0b013e3283330fb2

32. Pedersen HL, Horvei KD, Thiyagarajan D, Norby GE, Seredkina N, Moroni G, Eilertsen G, Holdaas H, Strøm EH, Bakland G, Meroni PL, Rekvig OP (2018) Lupus nephritis: low urinary DNase I levels reflect loss of renal DNase I and may be utilized as a biomarker of disease progression. J Pathol Clin Res 4:193-203. https://doi.org/10.1002/cjp2.99

33. Rauh R, Frost F, Korbmacher C (2020) Effects of syntaxins 2, 3 , and 4 on rat and human epithelial sodium channel $(\mathrm{ENaC})$ in Xenopus laevis oocytes. Pflügers Arch Eur J Physiol 472:461471. https://doi.org/10.1007/s00424-020-02365-6

34. Reihill JA, Walker B, Hamilton RA, Ferguson TE, Elborn JS, Stutts MJ, Harvey BJ, Saint-Criq V, Hendrick SM, Martin SL (2016) Inhibition of protease-epithelial sodium channel signaling improves mucociliary function in cystic fibrosis airways. Am J Respir Crit Care Med 194:701-710. https://doi.org/10. 1164/rccm.201511-2216OC

35. Rossier BC, Stutts MJ (2009) Activation of the epithelial sodium channel $(\mathrm{ENaC})$ by serine proteases. Annu Rev Physiol 71:361-379. https://doi.org/10.1146/annurev.physiol.010908. 163108
36. Rut W, Nielsen NV, Czarna J, Poreba M, Kanse SM, Drag M (2019) Fluorescent activity-based probe for the selective detection of Factor VII activating protease (FSAP) in human plasma. Thromb Res 182:124-132. https://doi.org/10.1016/j.thromres. 2019.08.016

37. Schork A, Woern M, Kalbacher H, Voelter W, Nacken R, Bertog M, Haerteis S, Korbmacher C, Heyne N, Peter A, Haring HU, Artunc F (2016) Association of Plasminuria with Overhydration in Patients with CKD. Clin J Am Soc Nephrol CJASN 11:761769. https://doi.org/10.2215/CJN.12261115

38. Subramaniam S, Thielmann I, Morowski M, Pragst I, Sandset PM, Nieswandt B, Etscheid M, Kanse SM (2015) Defective thrombus formation in mice lacking endogenous factor VII activating protease (FSAP). Thromb Haemost 113:870-880. https://doi.org/10. 1160/th14-06-0519

39. Wörn M, Bohnert BN, Alenazi F, Boldt K, Klose F, Junger K, Ueffing M, Birkenfeld AL, Kalbacher H, Artunc F (2021) Proteasuria in nephrotic syndrome-quantification and proteomic profiling. J Proteomics 230:103981. https://doi.org/10.1016/j.jprot.2020. 103981

40. Xiao M, Bohnert BN, Aypek H, Kretz O, Grahammer F, Aukschun U, Worn M, Janessa A, Essigke D, Daniel C, Amann K, Huber TB, Plow EF, Birkenfeld AL, Artunc F (2021) Plasminogen deficiency does not prevent sodium retention in a genetic mouse model of experimental nephrotic syndrome. Acta Physiol (Oxf) 231:e13512. https://doi.org/10.1111/apha.13512

41. Yamamichi S, Fujiwara Y, Kikuchi T, Nishitani M, Matsushita Y, Hasumi K (2011) Extracellular histone induces plasma hyaluronan-binding protein (factor VII activating protease) activation in vivo. Biochem Biophys Res Commun 409:483-488. https://doi. org/10.1016/j.bbrc.2011.05.030

42. Yang L, Frindt G, Lang F, Kuhl D, Vallon V, Palmer LG (2017) SGK1-dependent ENaC processing and trafficking in mice with high dietary $\mathrm{K}$ intake and elevated aldosterone. Am J Physiol Renal Physiol 312:F65-f76. https://doi.org/10.1152/ajprenal. 00257.2016

43. Yu Y, Kwon K, Pieper R (2019) Detection of neutrophil extracellular traps in urine. Methods Mol Biol (Clifton, NJ) 2021:241257. https://doi.org/10.1007/978-1-4939-9601-8_21

44. Zeerleder S (2018) Factor VII-activating protease: hemostatic protein or immune regulator? Semin Thromb Hemost 44:151-158. https://doi.org/10.1055/s-0037-1607431

Publisher's note Springer Nature remains neutral with regard to jurisdictional claims in published maps and institutional affiliations. 